\title{
The Impact of Islamic Finance Knowledge and Religiosity on Gold Investment Behavior: An Extended of The Theory of Planned Behavior
}

\author{
Achmad Nur Alfianto ${ }^{1}$, Anton Priyo Nugroho ${ }^{2}$ \\ \{achmadnuralfianto@gmail.com¹,priyo.nugroho@uii.ac.id ${ }^{2}$ \} \\ Master of Islamic Studies, Faculty of Islamic Studies, Islamic University of Indonesia, Yogyakarta, \\ Indonesia
}

\begin{abstract}
This study aimed to analyze the influence of knowledge of Islamic finance on the attitudes towards gold investment and to analyze the impact of religiosity on gold investment behavior using the Theory of Planned Behavior (TPB) approach tested on employees of Islamic financial institutions in the Regency of Magelang Indonesia. Data obtained from 205 respondents who were employees of 10 Islamic financial institutions and then analyzed using descriptive analysis and Structural Equation Modeling (SEM). The result showed that religiosity had a positive and significant influence on gold investment behavior. Also, the variables of attitude, subjective norm, and perceived behavioral control influenced positively and significantly the intention to invest in gold.
\end{abstract}

Keywords: Knowledge of Islamic Finance, Religiosity, Theory of Planned Behavior, Gold Investment.

\section{Introduction}

Gold is one of the instruments that has been developed by many financial institutions, including Islamic financial institutions. Gold investment in Islamic financial institutions began to develop with the issuance of DSN MUI regulation No. 77 / DSN-MUI / V / 2010 dated June 3, 2010, regarding the cashless transaction of gold. After the issuance of the DSN MUI regulation, most Islamic financial institutions began to develop gold investment products as a financial portfolio. PT. Bank Syariah Mandiri's business portfolio, the gold business records up by $14 \%$ year on year. The portfolio of gold pawn and gold installments of Bank Syariah Mandiri until April 2018 has reached a profit of Rp. 2.5 trillion in contrast to several Islamic financial institutions such as CIMB Niaga Syariah and BNI Syariah that no longer issue gold products as one of their superior products. It is due to the decline in the gold business. The financing value of CIMB Niaga Syariah gold products until mid-2016 is only around Rp. 200 billion, while the value of BNI Syariah gold pawn until the end of 2016 is only around Rp 20 billion, $10 \%$ less year on year [1].

As investment choices and financial facilities develop, the marketing strategy has become highly competitive. In order to get the maximum target and maintain the existence of gold investment products, the approach to market the gold investment product is by improving the service using several approach mechanisms. For Islamic financial institutions, the Islam brand attached to the institution is one of the attractions for customers and investors who are predominantly Muslim. Therefore the religious approach is one of the marketing strategies that considered effective. Also, current Islamic financial information can be accessed easily by 
the public. Various Islamic financial information is available and can be learned directly by the public. Those easy accesses to information can educate the public regarding Islamic finance.

The available information is not just about Islamic finance, but also about its products or services that can be obtained easily, including Islamic financial investment. Financial knowledge covers all aspects of financial concepts, from financial information to financial decision making [2]. Financial knowledge is all the things related to finance in everyday life that is the ability to understand and effectively apply various financial skills. It can be obtained by developing one's financial skills as well as learning to use financial tools in the process of making a decision. Financial knowledge also enables someone to make financial decisions more effectively [3].

The information and knowledge of Islamic finance will educate society before choosing their Islamic investment instruments. The development of financial knowledge also makes it necessary for gold investment institutions to market these products. The development theory on researched finance behavior mostly using the theory of planned behavior. Therefore, this study aims to analyze the effect of Islamic financial knowledge and religiosity on gold investment habits in society by using the TPB method. To predict and understand factors that can motivate someone's behavior using The theory of planned behavior as information in developing marketing strategies in the future.

\section{Literature Review}

\subsection{Theory of Planned Behavior (TPB)}

The theory of Planned Behavior is a unitary model that consists of four predictors of behavior, namely attitudes, subjective norms, behavioral control perception and intention to act. Predictors can directly affect the behavior, however, in a certain situation, or specific environment, or in the presence of personal obstacles, the intention factor alone may not be enough to predict behavior [4]. Thus, TPB is not a patent model instead it is a flexible behavioral model that can be developed or expanded by adding more predictor in which can explain the significant variance of intention [4].

Intention or intention to act is an overview of the motivational factors that affect individual behavior and a direct antecedent of behaviour. Intention can be measured directly by asking subjects that relate to a certain behavior. An individual's intentions are based on attitudes, subjective norms, and behavioral control perceptions. Another study conducted by Icek Ajzen stated that intention has a significant effect on the behavior of consumers. TPB shows that intention has a positive effect on the behavior of an individual to have certain preferences. According to Icek Ajzen, the intention was also a strong predictor of behavior which possessed an individual [5].

Attitude is a self-belief that is associated with ratings subjective individual about themselves and their environment. These beliefs are a description of behavioral consequences (behavioral beliefs) and are obtained based on personal beliefs [6]. Attitudes can be measured directly by asking a subject related to the belief and evaluation of a person to certain actions. Attitudes can be formed by three components, namely cognitive, affective, and conative [6]. Previous study on the behavior of consumers in determining what food to be consumed shows that attitudes influence positively and exhibited significantly against someone's decision in choosing specific food [5]. Another research shows that attitudes directly affect intention or 
intention to act. The results are in line with the Theory of Planned Behavior that is used to predict intentions [7].

Subjective norm is the perception of an individual to conduct certain actions from something that influences his/her life (significant others). Attitudes can be measured directly by asking a subject related to the belief and evaluation of a person to certain actions. Attitudes can be formed by three components, namely cognitive, affective, and conative. Icek Ajzen's study on the behavior of consumers in determining what food to be consumed shows that attitudes influence positively and exhibited significantly against someone's decision in choosing specific food [5]. Moreover, another previous study shows that the subjective norm is the strongest predictor of individual intention to do savings [8].

Perception of behavioral control (Perceive Behavioral Control) is the perception of an individual against the behavior of the ease or difficulty to realize specific behavior. Perceive Behavioral Control directly influence the individual intention to perform a behavior [6]. Perceive Behavioral Control can be measured as indirect and not direct. A study conducted by Ajzen [5], Xiao \& Wu [7], and Satsios \& Hadjidakis [8] shows that the perception of behavioral control directly affected the intention or the intention of a person to do something. The results are in line with the TPB that was used to predict intentions. The relationships of attitudes, subjective norm, perceived behavioral control, and intention to act in the TPB can be presented in the picture as follows:

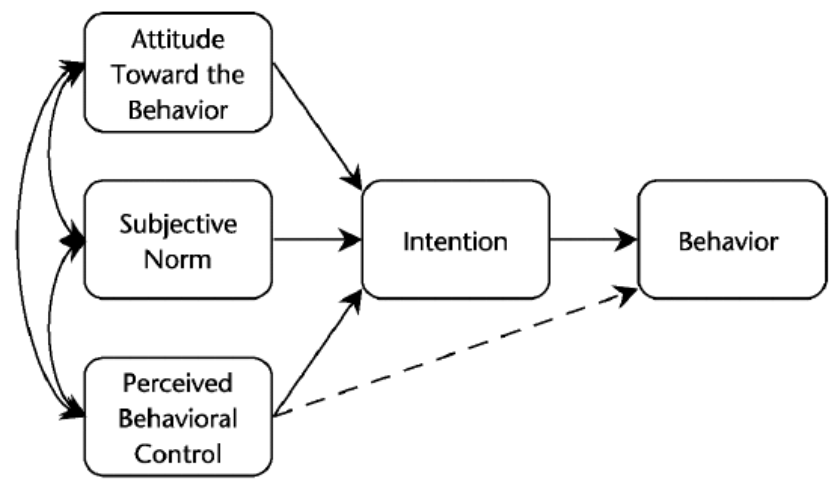

Fig.1. Theory of Planned Behavior

An individual's perception can also be influenced by many factors such as age, gender, ethnicity, economic and social status, education, level of religiosity, life values, experience, information, social support, and so forth. Background factors of an individual are divided into three categories, namely personal factors, social factors, and information factors. Kashif et al. [9] and Alam et al. [10] analyzed an extension of TPB in the context of investment by adding predictors of religiosity in the research model. His study illustrated that religiosity can be used in the TPB model and is one of the good predictors in the model. In addition to modifying the model by adding behavioral predictors, other researchers also expanded the study by adding new variables to predict attitude variables. Research conducted by Kashif et al. [9] and Cuong \& Jian [11] added Risk Knowledge and Experience variables as predictors of attitude. The study illustrates that these variables also influence an individual's attitude toward financial behavior.

Several studies have shown that TPB can be used in predicting the behavior of an individual in investing in gold [12]. Theory of Planned Behavior can also be used in predicting investment behavior and financial behavior of an individual [13]; [14]; [15]; [16]; [17]. 
Generally, TPB is also used to predict financial behavior in the context of Islamic finance, such as research conducted by Ibrahim \& Arshad [18] and Albashir et al. [19].

Previous research shows that investment behavior and financial behavior, in general, can be influenced by several factors such as demographic, economic, social, cultural, and psychological factors. In addition to these factors, other studies such as those conducted by Mahdzan et al. [20], Nugroho et al. [21], and Abduh \& Omar [22] show that religiosity is a factor that significantly affects the financial behavior of an individual. Another research conducted by Suppakitjarak [23], Edirisinghe et al. [24], Seetaraman et al. [25], and Zaman et al. [26], explains that financial knowledge factors also affect the financial behavior of an individual.

\subsection{Islamic Finance Knowledge}

Financial knowledge is an understanding of the basic concepts of finance, understanding of business models and business performance as measured by using a model to facilitate or support financial decision making [27]. Knowledge can be interpreted as practice, adaptability, understanding of a condition, understanding of regulations and norms in conducting financial activities [28]. Financial knowledge is also considered as a principle and terminology that is needed to succeed in managing and solving all personal financial problems [29]. Someone with good financial knowledge tends to have good financial responsibilities. Financial knowledge has a role in managing and solving problems in decision making. A person's good financial knowledge enables management and problem-solving in making better investment decisions [30].

The indicator is used to determine a person's level of financial knowledge which further developed and explained by [15]. The indicators of financial knowledge include General Financial Knowledge, Savings and Loans Knowledge, Basic Insurance Knowledge, and Basic Investment Knowledge. Yong et al. [31] found that there is a relationship between financial knowledge and individual attitude. . From the hypothesis test, it can be shown that financial knowledge has a positive and significant effect on the financial attitude of an individual [31]. In other financial contexts, financial knowledge is also found to be significantly related to financial behavior. Positive changes in financial knowledge indicate a positive change in the financial attitude of an individual [32].

Other research shows that the level of Islamic finance knowledge has a positive influence on financial planning and management. It indicated that an individual with a high level of understanding of Islamic finance tends to have good personal financial planning and management. The results of the study also showed that levels of knowledge of Islamic finance have positively affected someone's decisions on which type of investment to make [33]. Therefore, this condition has created a hypothesis as follows :

\section{H1: Knowledge of Islamic Finance has a positive and significant effect on Gold Investors' Attitude.}

\subsection{Religiosity}

Religiosity is derived from the word religion which is the uptake of languages Latin that says Religare which means binding. Religion can be defined as a bond of an individual toward something, so the word religious is personal and relates directly to the individual and his/her existence. Religion contains rules and obligations that must be implemented. Those rules and 
obligations are binding and play a role to complete individual or group relationships with God, fellow human beings and the natural surroundings [34].

Religion also has the same meaning as Agama. The word Agama comes from the language of Sansekerta that is the word "a" which means no, and "gama" which means chaotic. Therefore, Agama can be interpreted as something that is not chaotic or orderly because religion contains certain rules [35]. Agama or religion in someone's life plays a role as a value system that contains certain norms. In general, these norms guide someone's acts or behaviors. It is intended that each individual's behavior remains in accordance with the religious rules that have been adopted. According to El-Menouar [36], there are five dimensions of religiosity in Islam, which are : the ideological dimension/belief, the ritualistic dimension, the experiencial dimension, the intellectual dimension/ knowledge and the consequential dimension.

Religiosity has a positive and significant effect on the behavior of customers who use the products and services of Islamic banks. This result is strengthening the developing theoretical model to study the influence of religiosity on the individual behavior of using the Islamic Bank. The results prove that religiosity is a strong predictor of behavior, stronger than intentions variable. It shows that the model of TPB can be developed by adding some variables of behavior predictors and can be used to predict a variety of different behaviors [21]. Religiosity also affects the behavior of customers who are Muslim communities in Barcelona, Spain in utilizing Islamic bank products and services. As minorities in Barcelona, religion became one of the strongest motivations of the customers. There is a positive and significant relationship between attitudes and motivations of religiosity in using the services of the Islamic bank. The more powerful the religious motivation, the more interested the Muslims in Spain to take advantage of the products and services of Islamic banks. It supports the use of TRA in Islamic finance behavior [37].

The faith and religiosity of an individual play an important role in influencing the desire of investors to invest in Socially Responsible Investing (SRI) in Poland. It shows that people in Poland began to assume that combines aspects of religion to the practice of business and investment are very important. The selection of the type of investment is not only based on the amount of the return, but also its value of social responsibility [38]. Therefore, this condition has created a hypothesis as follows:

\section{H2: Religiosity has a positive and significant effect on Gold Investment Behavior.}

Based on the above descriptions, the research model of this study is as shown below:

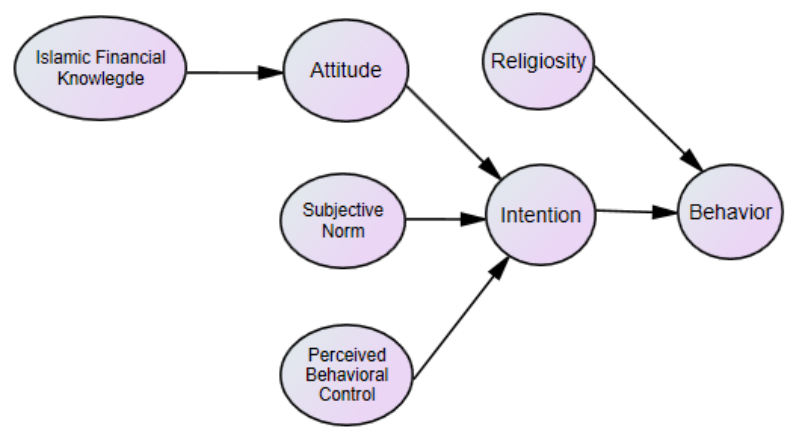

Fig.2. Research Model 


\section{Research Methods}

This study used a quantitative method by using a social approach. Data were obtained using a questionnaire. The object of research were employees of the Institute of Islamic Finance in the City and District of Magelang who never invest the gold, jewelry, or other forms of gold investment. The study was conducted from July to August 2019. The samples used in the study were selected by using the Purposive Sampling method, which is a technique of determining the sample with a certain consideration. The characteristics of the samples were:

a) Respondents are employees who work in Islamic financial institutions operating in the City and District of Magelang and have worked for at least 2 (two) years. These characteristics are used to measure the level of Islamic Finance Knowledge so that the results will not too diverse.

b) Respondent is someone who has invested gold in the form of metals, jewelry and other forms of gold investment.

c) Respondents are Muslim men or women.

The number of samples that are used in research this was 205 respondents who are employees of 10 Islamic finance institutions in the City and District of Magelang. This study used primary data collected through a questionnaire. Fifty questionnaires were distributed online and 238 questionnaires were distributed directly to the respondents in 20 Islamic finance institutions. There were seven variables that consist of four exogenous variables and three endogenous variables. Exogenous variables consisted of Islamic Finance Knowledge, Religiosity, Subjective Norms, and Behavioral Control Perception, while endogenous variables consisted of Attitude, Intention, and Golden Investment Behavior. Each of these variables was presented in a statement in the questionnaire by using reference studies beforehand as shown in the table as follows:

Table 1. Research Instruments

\begin{tabular}{lll}
\hline No & Variables & Reference \\
\hline 1. & Islamic Finance Knowledge & Doriana Cucilleni [15] \\
2. & Attitude & Doriana Cucilleni [15] and Celia Ray Hayhoe [39] \\
3. & Subjective norms & Brian P. Kennedy [40] and Doriana Cucilleni [15] \\
4. & Behavioral Control Perception & Brian P. Kennedy [40] and Doriana Cucilleni [15] \\
5. & Intention & Brian P. Kennedy [40] \\
6. & Religiosity & Hasan Terzi [41] \\
7. & Investment Behavior & Jing Jian Xiao [42] \\
\hline
\end{tabular}

The statements in the questionnaire were measured using a CRS measurement scale. Research instrument which already passed the validity and reliability test was tested using SPSS 16.0.

To find out the relationship between variables, data were analyzed using SEM which is one of the multivariate analysis techniques. In analyzing data using SEM, this study used AMOS 20.0 software. The result showed that the study already met the criteria of Validity Convergent, Validity Discriminant and Reliability Construct / Composite test with the CR value $>0.7$. The Kolmogorov-Smirnov test showed a significance of $>0.05$ so that the data used in the study was confirmed as normal data. 


\section{Results And Discussion}

Based on demographics factors, $61.46 \%$ of the respondents were male. Around $48.29 \%$ of respondents were $26-35$ years old, $23.41 \%$ were $36-45$ years old, $17.56 \%$ were $17-25$ years old, and the rest was more than 46 years old. In addition to that, $47.32 \%$ of respondents have obtained a Bachelor degree, 39.02\% were high school graduates, $12.20 \%$ were Diploma graduate, and the rest was Master graduates. Around 51.22\% of employees had 2-6 years of working experience and the rest have worked for more than 7 years. Around $57.56 \%$ of employees had income between IDR 1-3 million, $29.27 \%$ has an income of IDR 3-5 million, and the rest had an income of more than IDR 5 million.

This study shows that $64.88 \%$ of respondents had an investment in the form of gold jewelry, $22.44 \%$ in the form of gold bullion, $9.27 \%$ in the form of gold savings, and $3.41 \%$ in the form of gold credit. Around $83.9 \%$ or a majority of respondents had a gold investment of fewer than 25 grams, $14.63 \%$ of respondents had gold investment between 25-50 grams, and the rest had more than 50 grams. Most respondents $(45.85 \%)$ traded gold at a certain time or while having particular needs.

\subsection{Model Equation Test}

Test Equation Model was done by estimating the model as a whole by simply inserting an indicator that meets the test of the analysis of the confirmatory factor analysis (CFA) for each exogenous and endogenous construct. The results can be obtained the results as follows :

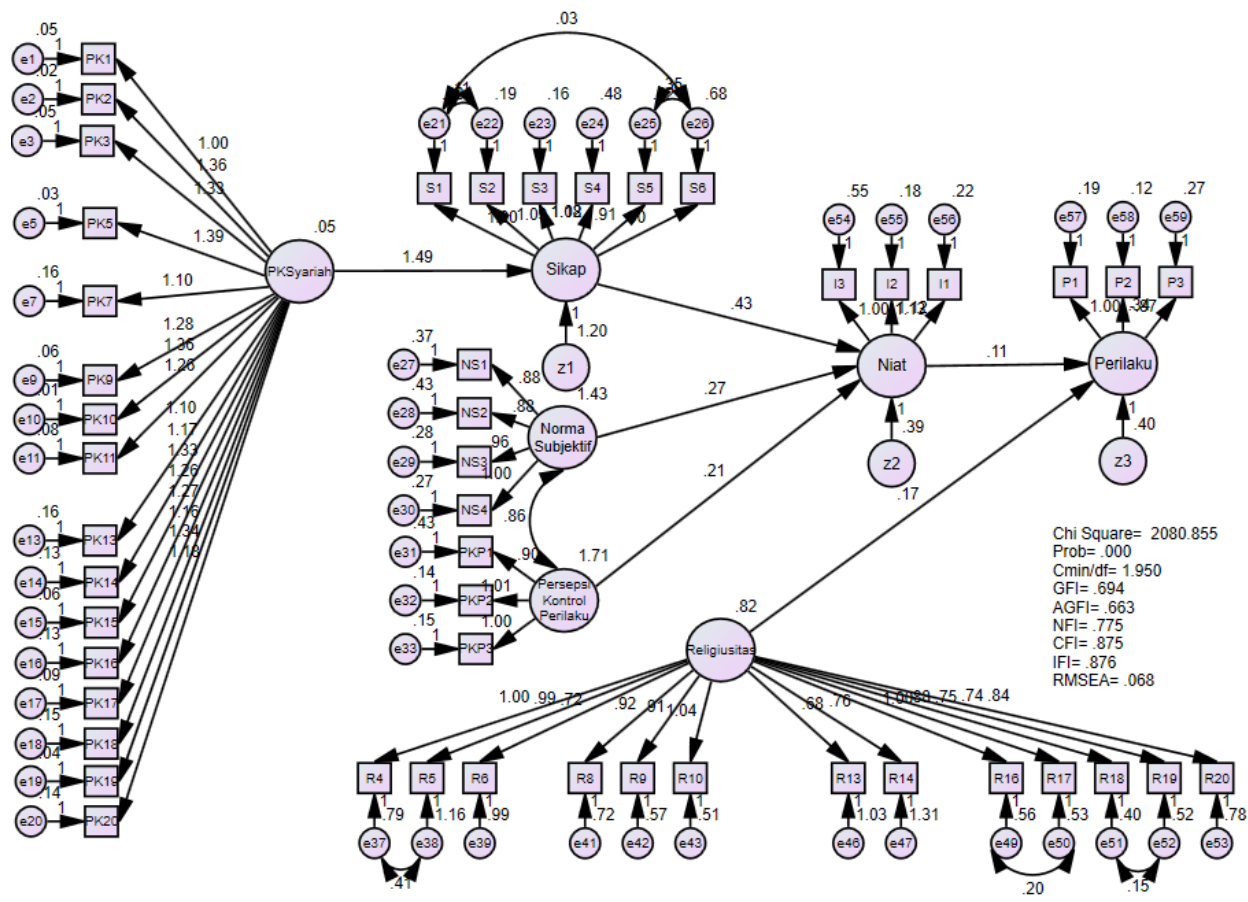

Fig.3. Structural Equation Source: AMOS Output 
Table 2. Structural Equation of the Goodness of Fit Index

\begin{tabular}{llll}
\hline Goodness of Fit Index & Cut off Value & Model Result & Note \\
\hline Probabilitas Chi Square & $\mathrm{P} \geq 0,05$ & 0,000 & Poor Fit \\
GFI & $\geq 0,90$ & 0,694 & Poor Fit \\
AGFI & $\geq 0,90$ & 0,663 & Poor Fit \\
NFI & $\geq 0,90$ & 0,775 & Marginal Fit \\
TLI & $\geq 0,90$ & 0,868 & Marginal Fit \\
CFI & $\geq 0,90$ & 0,875 & Marginal Fit \\
IFI & $\geq 0,90$ & 0,876 & Marginal Fit \\
RMSEA & $\leq 0,08$ & 0,068 & Fit \\
CMIN/DF & $\leq 2,00$ & 1,950 & Fit \\
\hline
\end{tabular}

Source: AMOS Output

Table 2 and figure 3 shows that the overall criteria of the feasibility of the model were suitable to be used in this study.

\subsection{Hypothesis Test}

The research hypothesis test was tested through the SEM results of parameter estimation by using AMOS 20.0 software. Hypothesis testing was done based on the following table:

Table 3. Estimated Value and Probability of Hypothesis Test

\begin{tabular}{lllll}
\hline & & & Estimate & $\mathrm{P}$ \\
\hline Attitude & $<---$ & Islamic_Finance_Knowledge & .289 & $* * *$ \\
Intention & $<---$ & Subjective_Norm & .336 & $* * *$ \\
Intention & $<---$ & Perceive_Behavioral_Control & .288 & $* * *$ \\
Intention & $<---$ & Attitude & .520 & $* * *$ \\
Behaviour & $<---$ & Intention & .158 & .026 \\
Behaviour & $<---$ & Religiosity & .229 & .008 \\
\hline
\end{tabular}

Source: AMOS Output

Table 3 shows that attitude has a positive and significant effect on the intention of gold investment. Therefore, attitude can be used as predictors of intention to behave, in accordance with the previous studies conducted by Satsios \& Hadjidakis [8]; Nugroho[21]; Kennedy [40]; Seni \& Ratnadi [43].

Subjective norms also have a positive and significant effect on the Intention of Gold Investment. A positive relationship between the subjective norms and the intention to act can be interpreted that the intention of an individual to invest in gold is influenced by nonpsychological factors, such as encouragement from friends, relatives, parents, and other surroundings [12]; [44]. The result also showed that the subjective norm can be used as predictors of intention to act or intention to invest, in accordance with the previous studies conducted by Dayaratne \& Wijethunga [14]; Ibrahim \& Arshad [18]; Sondari et al. [45].

In addition, this study shows that Behavioral Control Perception has a positive and significant effect on the Intention of Gold Investment. This positive relationship means that the stronger the perception of behavior control of an individual toward gold investment, the higher the intention of someone to invest in gold. This is in line with previous studies conducted by Fauzi et al. [44]. The results of the study also showed that the perception of 
behavioral control can be used as predictors of intention to act or intention to invest, in accordance with the previous studies conducted by Ali et al. [13] and Ibrahim \& Arshad [18]. It also can be used as a predictor of behavioral intention to use financial products [7]; [15].

The intention has a positive and significant effect on gold investment behavior. Results of the study also showed that intention to act can be used as predictors of financing behavior, in accordance with the previous studies conducted by Xiao \& Wu [7] and Kennedy [40].

\subsection{Analysis and Discussion}

Research shows that the data and research findings support all the proposed research hypotheses. The first hypothesis is about the influence of Islamic Finance Knowledge on the Gold Investment Attitude. With an estimated parameter value of 0.289 , Islamic financial knowledge is proven to be positively and significantly influence the attitude, and the relationship between the two variables is weak. This study also shows that the knowledge of Islamic finance can directly have a positive and significant effect on attitude. It means that the higher the Islamic financial knowledge an individual has, the better his/her investment behavior.

Generally, the direct relationship between financial knowledge and financial attitude is in line with previous research conducted by Zaman et al. [26] and Yong et al. [31]. In addition, previous research conducted by Zainul Arifin [46] found that an individual with a higher educational background will have good financial knowledge, and good financial knowledge will lead them to have good financial attitude and management.

Knowledge is closely related to individual attitude. The attitude of an individual with a high level of knowledge will be different from an individual with a low level of knowledge. Someone with good financial knowledge will tend to choose the best investment instruments. This is in line with Allah's words in al-Zumar verse 18 which means:

"Who listen to speech and follow the best of it. Those are the ones Allah has guided, and those are people of understanding”.

Besides, Allah SWT also said in Surah al- Isra ' verse 36, which means :

"And do not pursue that of which you have no knowledge. Indeed the hearing, the sight and the heart about all those (one) will be questioned".

Those verses describe that one of the signs people with knowledge are obeying and choosing something (reference) useful as well as doing the best thing from that reference. Allah also reminded us about the importance of knowing and to understand what we do before actually doing it. It is also can be interpreted that the importance of having Islamic financial knowledge before doing a transaction, especially in investing gold. Hence, the gold investment activity is not only based on trends or by following most people, however, but it is also essential to prepare the investors with knowledge of necessary Islamic finance before they invest.

The second hypothesis was about the effect of religiosity on gold investment attitude. The value of the estimated parameter was 0.229 . Therefore religiosity has a positive and significant effect on the attitude. The relationship between the two variables was weak. This result indicates that religiosity has a positive and significant effect on individual attitudes. Positive relationships mean that the more religious someone is, then more likely for them to invest in 
gold. Positive relationships mean that the more religious someone is, then more likely for them to invest in gold. The results are in line with the previous study done by Amin [12].

Besides, this study also shows that religiosity is one of the predictors of attitude. An individual with a high level of religiosity will tend to do the good deed. For example, someone with high religiosity will tend not to use excessive wealth and spend their wealth in the way of Allah. As Allah SWT said in al-Furqan verse 67, which means:

"And (they are) those who, when they spend, do so not excessively or sparingly but are ever, between that, (justly) moderate.".

Gold investment product particularly has become one of the products of financing and funding in some Islamic financial agencies. It allows a religious individual to use gold as their Islamic financial agency's products. It is also in line with the previous study by Nugroho [21]; Abduh \& Omar [22]; Lajuni et al. [48] which show that religiosity affects the use of the Islamic bank product and Islamic financial attitude.

In TPB, someone's attitude tends to affect their intention to act. One of the behavioral indicators is pleased with something and happy to do something. Someone who has a pleasing feeling to something will tend to have the intention to do those things that make them happy, so also applies vice versa. As Allah SWT said in Surah al- Hijr verse 3, which means:

"Let them eat and enjoy themselves and be diverted by (false) hope, for they are going to know”.

That verse describes that excessive fun can influence someone to tend to be negligent. Besides attitude, the subjective norm is one of the factors that influence one's intention to act. Subjective norms are external factors that come from the influence of family, friends, influential people, and the environment. In this regard, it has been described in a Hasan Hadith narrated by Imam Abu Dawud in his Sunan (No. 4833), at-Tirmidhi in his Sunan (No. 2379) which said:

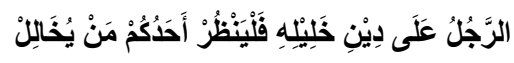

"A man follows the religion of his friend, so each one should consider whom he makes his friend".

Hadith is rated as hasan by al - ' Alamah al Abani Rahimahullah in US- Lineage Ash Shahihah, No. 92.

In the Hadith muttafaq ' alaih from Bukhari, the book adh-Dzaba'ih wa Ash Shaid, No. 5534; Muslim, Kitab al-Birr wa Ash- Shillah wa al- Adab, No. 2628 Rasulullah SAW. also said:

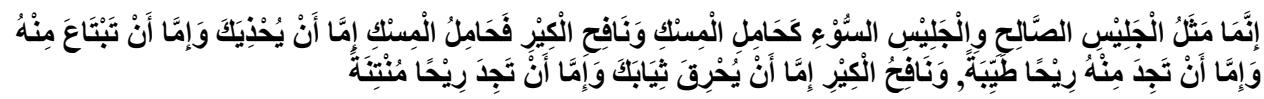

"The example of a good pious companion and an evil one is that of a person carrying musk and another blowing a pair of bellows. The one who is carrying musk will either give you some perfume as a present, or you will buy some from him, or you will get a good smell from 
him, but the one who is blowing a pair of bellows will either burn your clothes or you will get a bad smell from him".

Besides religiosity, in this study, the intention to act was closely related to the attitude carried out. Intentions are beliefs that are oriented towards specific goals, whereas attitude is a response to behavioral intentions. In this connection, Allah SWT. said in surah al-Baqarah verse 284 which means:

"To Allah belongs whatever is in the heavens and whatever is in the earth. Whether you show what is within yourselves or conceal it, Allah will bring you to account for it. Then he will forgive whom he wills and punish whom he wills, and Allah is over all things competent".

That verse shows that intention is something that comes from the heart, while behavior or action is an outward expression of an intention. In the theory of planned behavior, the intention is considered as a predictor of behavior. That term is in line with a hadith as follows:

$$
\text { إنَّمَا الأعمَال بالنِّيَّاتِ و إنَّمَا لِكُلِّ امريعٍ ما نَوَى }
$$

"Verily actions are by intentions, and for every person is what he intended" [49]

The above description shows that there is a positive relationship between intentions and behavior. It means that the more intention someone to invest in gold, the more likely for them to do the investment.

Investments in the form of gold metal are one of the effective investments in today's era of the global economy. Amid the high inflation rate, investing in the gold medal is considered good. Gold becomes the most wanted of most large investors because it has stable value and increases price trends compared to other investments product [50]. This condition is also in line with the hadith of Rasulullah SAW. which was narrated by Ahmad No. 16569 as follows:

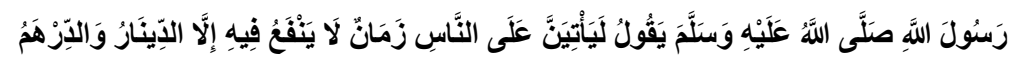

"A time is certainly coming over mankind in which there will be nothing (left) that will be of use (or benefit) save a Dinār (i.e., a gold coin) and a Dirham (i.e., a silver coin)".

Besides the price trend which tends to rise and the high profits earned, gold also has hedging value. Hedging is an investment that is done with the purpose to reduce the risk of other investments. Hedging can be interpreted as a strategy that is done to reduce unexpected business risk and allow someone to still get profit from their investment [51].

By having hedging value, in a long period with a high rate of inflation, gold can protect its value from inflation effects (inflation hedge). An inflation hedge is an investment that provides protection value on the declining currency purchase as a result of the increasing price of goods. This investing activity will help protect the value of an investment over a certain period. This is in accordance with the hadith of the Prophet Muhammad which is narrated by Imam Bukhari Book 56, Hadith 836 as follows : 


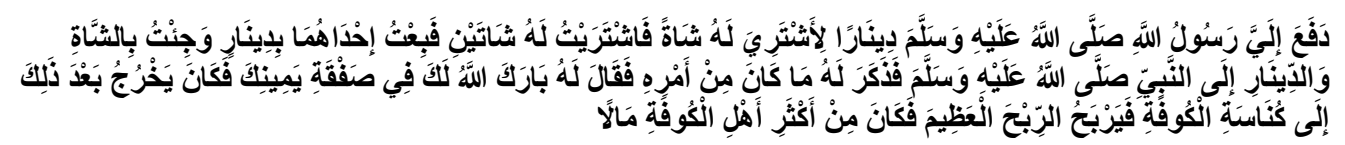

"Narrated 'Urwa: that the Prophet gave him one Dinar so as to buy a sheep for him. 'Urwa bought two sheep for him with the money. Then he sold one of the sheep for one Dinar, and brought one Dinar and a sheep to the Prophet. On that, the Prophet invoked Allah to bless him in his deals.".

\section{Conclusion}

This study shows that attitude, which is a factor of motivation and predictors of intention to act in TPB, also can be predicted by using a background factor, namely Islamic Financial Knowledge. Islamic financial knowledge is a cognitive aspect of behavior. This study found that around $45.37 \%$ of the respondents had high levels of Islamic financial knowledge, especially in gold investment. Around $38.05 \%$ were at a medium level, and $16.59 \%$ categorized as inferior.

To improve the knowledge of Islamic finance, the institution should educate the employees about gold investment products. This knowledge will allow them to understand the information very well and able to explain the gold investment product to prospective investors. Direct information from the employee could also educate the investors, so there is a big chance that the investors understand how to use gold as their investment.

This study found that the gold investment behavior on the employee of Islamic financial institutions in the City and District of Magelang influenced by the intention to invest in gold and religiosity. When the two variables compared, religiosity has an estimated parameter value of 0.229 . It interpreted that the level of religiosity will determine which investment product to use. Religiosity is seen from several aspects, such that the product of gold investment in Islamic financial institutions regulated by the DSN MUI and by the perspective of the Islamic economy. There are also verses of the Quran and al-Hadith which mention the benefit of gold. These proofs can be used as the strategies in gold investment products marketing by referring to the aspect of religiosity.

For further study, researchers can develop TPB by adding different variables or using other behavioral theories as well as other research models used in research in order to compare the results. Moreover, the next study can also use samples from other areas and focusing on one of the products of gold investment in Islamic financial institutions.

\section{References}

[1] Yoliawan, "CIMB Niaga Syariah dan BNI Syariah Tutup Bisnis Gadai Emas,” 2018. [Online]. Available: https://ekonomi.kompas.com/read/2018/05/22/151328926/cimb-niaga-syariah-danbni-syariah-tutup-bisnis-gadai-emas.

[2] A. L. and O. S. Mitchell, "The Economic Importance of Financial Literacy: Theory and Evidence," J. Econ. Lit., vol. Vol LII, 2014.

[3] C. A. Robb and A. S. Woodyard, "Ej941903," Financ. Knowl. Best Pract. Behav., no. 205, pp. 60-70, 2011

[4] I. Ajzen, "The theory of planned behavior," Organ. Behav. Hum. Decis. Process., vol. 50, no. 2, 
pp. 179-211, 1991, doi: 10.1016/0749-5978(91)90020-T.

[5] I. Ajzen, "Consumer attitudes and behavior: the theory of planned behavior applied to food consumption decisions," Riv. di Econ. Agrar., vol. 70, no. 2, pp. 121-138, 2015, doi: 10.13128/REA-18003.

[6] I. Ajzen, "Ajzeni-2005-attitudes-personality-and-behaviour-2nd-ed-open-university-press.pdf," International Journal of Strategic Innovative Marketing, vol. 3. p. 117, 2005.

[7] J. J. Xiao and J. Wu, "Completing debt management plans in credit counseling: An application of the theory of planned behavior," J. Financ. Couns. Plan., vol. 19, no. 2, pp. 29-45, 2008.

[8] N. Satsios and S. Hadjidakis, "Applying the Theory of Planned Behaviour (TPB) in saving behaviour of Pomak households," Int. J. Financ. Res., vol. 9, no. 2, pp. 122-133, 2018, doi: 10.5430/ijfr.v9n2p122.

[9] M. Kashif, A. Zarkada, and R. Thurasamy, "The moderating effect of religiosity on ethical behavioural intentions: An application of the extended theory of planned behaviour to Pakistani bank employees," Pers. Rev., vol. 46, no. 2, pp. 429-448, 2017, doi: 10.1108/PR-10-2015-0256.

[10] S. S. Alam, H. Janor, Zanariah, C. A. C. Wel, and M. N. Ahsan, "Is Religiosity an important factor in influencing the intention to undertake Islamic home financing in Klang Valley?," World Appl. Sci. J., vol. 19, no. 7, pp. 1030-1041, 2012, doi: 10.5829/idosi.wasj.2012.19.07.392.

[11] P. K. Cuong and Z. Jian, "Factors Influencing Individual Investors' Behavior: An Empirical Study of the Vietnamese Stock Market," Am. J. Bus. Manag., vol. 3, no. 2, pp. 77-94, 2014, doi: $10.11634 / 216796061403527$.

[12] H. Amin, "Journal of Internet Banking and Commerce (http://www.icommercecentral.com/) Willingness to Open Islamic Gold Investment Accounts," no. January, 2016.

[13] S. Ali, R. Zani, and K. Kasim, "Intention - behaviour relations : A conceptual and literature review," Res. J. Financ. Account., vol. 5, no. 19, pp. 168-178, 2014.

[14] D. A. I. Dayaratne and A. W. G. C. . Wijethunga, "Impact of psychology on behavioral intention in investing in capital markets: A survey of Colombo Stock Exchange | IJABF," Int. J. Account. Bus. Financ., no. 2, pp. 37-45, 2015.

[15] D. Cucinelli, G. Gandolfi, and M.-G. Soana, "Customer and Advisor Financial Decisions: the Theory of Planned Behavior Perspective,” Int. J. Bus. Soc. Sci., vol. 7, no. 12, pp. 80-92, 2016.

[16] M. Islamoğlu, M. Apan, and A. Ayvali, "Determination of factors affecting individual investor behaviours: A study on bankers," Int. J. Econ. Financ. Issues, vol. 5, no. 2, pp. 531-543, 2015.

[17] A. C. Ayudya and A. Wibowo, "The Intention to Use E-Money using Theory of Planned Behavior and Locus of Control," J. Keuang. dan Perbank., vol. 22, no. 2, pp. 335-349, 2018, doi: $10.26905 / \mathrm{jkdp} . v 22 \mathrm{i} 2.1691$.

[18] Y. Ibrahim and I. Arshad, "Examining the impact of product involvement, subjective norm and perceived behavioral control on investment intentions of individual investors in Pakistan," Invest. Manag. Financ. Innov., vol. 14, no. 4, pp. 181-193, 2017, doi: 10.21511/imfi.14(4).2017.15.

[19] W. A. Albashir, Y. Zainuddin, and S. K. Panigrahi, "The Acceptance of Islamic Banking Products in Libya: A Theory of Planned Behavior Approach," Int. J. Econ. Financ. Issues, vol. 8, no. 3, pp. 105-111, 2018.

[20] N. S. Mahdzan, R. Zainudin, R. Che Hashim, and N. A. Sulaiman, "Islamic religiosity and portfolio allocation: the Malaysian context," Int. J. Islam. Middle East. Financ. Manag., vol. 10, no. 3, pp. 434-452, 2017, doi: 10.1108/IMEFM-11-2016-0162.

[21] A. P. Nugroho, A. Hidayat, and H. Kusuma, "The influence of religiosity and self-efficacy on the saving behavior of the slamic banks," Banks Bank Syst., vol. 12, no. 3, pp. 35-47, 2017, doi: 10.21511/bbs.12(3).2017.03.

[22] M. Abduh and M. A. Omar, "Islamic- Bank Selection Criteria in Malaysia: An AHP Approach," Bus. Intell. J., vol. 5, no. 2007, pp. 271-281, 2012.

[23] N. Suppakitjarak and P. Krishnamra, "Household Saving Behavior and Determinants of the Forms of Saving and Investment in Thailand," J. Econ. Bus. Manag., vol. 3, no. 3, pp. 326-330, 2015, doi: 10.7763/joebm.2015.v3.204. 
[24] Edirisinghe, Kerrthipala, and Amarasinghe, "Financial Literacy And Financial Behavior Of Management Undergraduates Of Sri Lanka," Int. J. Manag. Appl. Sci., vol. Vol 3, no. Issue 1, 2017.

[25] Seetaraman, I. Niranjan, N. Patwa, and A. Kejriwal, "A Study of the Factors Affecting the Choice of Investment Portfolio by Individual Investors in Singapore," Account. Financ. Res., vol. Vol 6, no. Issue 3, 2017.

[26] Z. Zaman, B. Mehmood, R. Aftab, M. Shahid, and Y. Ameen, "Role of Islamic Financial Literacy in the Adoption of Islamic Banking Services: An Empirical Evidence from Lahore, Pakistan," J. Islam. Bus. Manag., vol. 7, no. 2, pp. 230-247, 2017, doi: 10.26501/jibm/2017.0702-006.

[27] S. A. Rahman, A. Tajudin, A. Fadzli, and A. Tajuddin, "Determinant Factors of Islamic Financial Literacy In Malaysia,” Am. J. Humanit. Soc. Sci. Res., no. 10, pp. 125-132, 2018.

[28] K. Jacob, S. Hudson, and M. Bush, "Tools for Survival: An Analysis of Financial Literacy Programs For Lower-Income Families,” RSA J., vol. 2012, no. June 1, pp. 24-27, 2000.

[29] E. Garman, "The business case for financial education," Pers. Financ. Work. Product., vol. 2, no. 1 , pp. 81-93, 1998.

[30] M. A. H. and J. M. Hogarth, "Household Financial Management: The Connection between Knowledge and Behavior," Federal Reserve Bulletin, 2003.

[31] C. C. Yong, S. Y. Yew, and C. K. Wee, "Financial knowledge, attitude and behaviour of young working adults in Malaysia," Institutions Econ., vol. 10, no. 4, pp. 21-48, 2018.

[32] J. Serido, S. Shim, and C. Tang, "A developmental model of financial capability: A framework for promoting a successful transition to adulthood," Int. J. Behav. Dev., vol. 37, no. 4, pp. $287-$ 297, 2013, doi: 10.1177/0165025413479476.

[33] S. Arum Setyowati, Harmadi, "Islamic Financial Literacy and Personal Financial Planning: A Socio-Demographic Study," J. Keuang. dan Perbank., vol. Vol 22, no. No 1, 2018.

[34] Subandi, Psikologi Agama \& Kesehatan Mental. Pustaka Pelajar: Yogyakarta, 2013.

[35] A. A. Ahyadi, Psikologi Agama. Bandung: Martiana, 1981.

[36] Y. El-Menouar, "The Five Dimensions of Muslim Religiosity . Results of an Empirical Study," Method, Data, Anal., vol. 8, no. 1, pp. 53-78, 2014, doi: 10.12758/mda.2014.003.

[37] A. Kaakeh, S. Van-Hemmen, and K. Hassan, "Universitat Autònoma de Barcelona Behavioural Finance in Islamic Finance, A new Approach," 2018.

[38] M. Czerwonka, "The Influence of Religion on Socially Responsible Investing," J. Relig. Bus. Ethic, vol. Vol 3, no. 21, 2014.

[39] C. R. Hayhoe, L. Leach, P. R. Turner, and Mo, "Discriminating the number of credit cards held by college students using credit and money attitudes *," J. Econ. Psychol., vol. 20, no. 6, pp. 643-656, 1999, doi: 10.1016/S0167-4870(99)00028-8.

[40] B. P. Kennedy, "The theory of planned behavior and financial literacy: A predictive model for credit card debt?," Theses, Diss. Capstones. Pap. 480, p. 84, 2013, doi: Paper 480.

[41] H. Terzi, B. A. Alserhan, and R. Altunsik, "The Relationship between Religiosity and Consumer Behavior among Arab, Turkish, and Indonesian Students: Testing an 8th Century A.D. Measure of Islamic Religiosity," Int. J. Teach. Case Stud., vol. 7, no. 3, pp. 207-222, 2016

[42] J. J. Xiao, "Handbook of consumer finance research," Handb. Consum. Financ. Res., no. August, pp. 1-424, 2008, doi: 10.1007/978-0-387-75734-6.

[43] N. N. A. Seni and N. M. D. Ratnadi, "Theory of Planned Behavior Untuk Memprediksi Niat Berinvestasi," E-Jurnal Ekon. dan Bisnis Univ. Udayana, vol. 12, p. 4043, 2017, doi: 10.24843/eeb.2017.v06.i12.p01.

[44] A. Fauzi, A. Wahab, H. A. Rahim, M. F. Sabri, M. A. Othman, and R. M. Rasdi, "GOLD INVESTMENT INTENTION AMONG URBAN PUBLIC SECTOR EMPLOYEES IN MALAYSIA," MALAYSIAN J. Consum. Fam. Econ., 2016.

[45] M. C. Sondari, P. Rufaidah, and S. Djatnika, "Using Theory of Planned Behavior in Predicting Entrepreneurial Career Intention,” vol. 2011, no. Iicies, pp. 137-141, 2015.

[46] A. Zainul Arifin, "Influence of financial attitude, financial behavior, financial capability on financial satisfaction," vol. 186, no. INSYMA, pp. 100-103, 2018, doi: 10.2991/insyma- 
18.2018.25.

[47] Departemen Agama RI, Al-Qur'an dan Terjemahnya. Jakarta: Sygma Exgrafika, 2009.

[48] N. Lajuni, I. Bujang, A. A. Karia, and Y. Yacob, "Religiosity, Financial Knowledge, and Financial Behavior Influence on Personal Financial Distress Among Millennial Generation," $J$. Manaj. dan Kewirausahaan, vol. 20, no. 2, pp. 92-98, 2018, doi: 10.9744/jmk.20.2.92-98.

[49] A.-I. J. 'Abdurrahman bin A. B. As-Suyuthi, Al Ashbah wan Nadha'ir fil furu'. Semarang: Toha Putra, 2008.

[50] M. Shahril Ahmad Razimi, A. Rahim Romle, and K. Anuar Azizan, "An Understanding of Shariah Issues on Gold Investment: A Review,” Asian J. Bus. Manag. Stud., vol. 8, no. 1, pp. 912, 2017.

[51] H. Prabowo and N. Fitri, “, Investasi Emas Sebagai Alat Hedging Untuk Mengatasi Inflasi: Studi Kasus Di Indonesia Dengan Melihat Pengaruh Expected dan Unexpected Inflasi Terhadap Return Emas Periode Tahun 2004-2013," 2016. 